Syntax Literate: Jurnal Ilmiah Indonesia p-ISSN: 2541-0849

e-ISSN: 2548-1398

Vol. 6, No. 4, April 2021

\title{
MODEL MANAJEMEN PEMBELAJARAN BLENDED LEARNING PADA MASA PANDEMI COVID-19
}

\section{Suhairi dan Jumara Santi}

Program Studi Manajemen Pendidikan Islam Pascasarjana Universitas Islam Negeri

Sunan Gunung Djati Bandung, Indonesia

Email: suhairieni@gmail.com dan santijumara@gmail.com

\section{Abstract}

The research objective in this study was to explain the management model of Blended Learning during the Covid-19 pandemic at SMP Negeri 01 Kisam Ilir with a focus on managing blended learning it self. The research approach used is qualitative research. The research method uses descriptive methods. Data collection techniques using observation techniques, in-depth interviews, and documentation. Data analysis was processed through data reduction, data presentation, and verification. Checking the validity of the data using credibility, confirmability, transferability, and dependability techniques. The results of the study concluded that South Sumatra Province provided provisions for the yellow and green zone for the spread of covid-19 to be able to carry out face-to-face learning with applicable provisions, SMP Negeri 01 Kisam Ilir had planned, implemented and carried out blanded learning based learning assessments, the power of Blended Learning lies in more efficient learning because teachers and students can communicate both offline and online, the weakness is that students are less active in submitting responses on whatsapp groups and also the practice of copying and pasting online assignments between students is increasingly prevalent. The ideal Blended Learning Learning Model is to combine synchronous and asynchronous learning.

Keywords: learning; blended learning; management functions

\section{Abstrak}

Tujuan penelitian ini adalah menjelaskan model manajemen pembelajaran blended learning pada masa pandemi Covid-19 di SMP Negeri 01 Kisam Ilir dengan fokus pada pengelolaan pembelajaran blended learning itu sendiri. Pendekatan penelitian yang digunakan adalah penelitian kualitatif. Metode penelitian menggunakan metode deskriptif. Teknik Pengumpulan data menggunakan teknik observasi, wawancara mendalam, dan dokumentasi. Analisis data diproses melalui reduksi data, penyajian data, dan verifikasi. Pengecekan keabsahan data menggunakan teknik credibility, confirmability, transferability, dan dependenbility. Hasil penelitian menyimpulkan bahwa Provinsi Sumatera Selatan memberikan ketentuan bagi daerah zona kuning dan hijau penyebaran covid-19 untuk dapat melaksanakan pembelajaran tatap muka dengan ketentuan yang berlaku, SMP Negeri 01 Kisam Ilir telah merencanakan, melaksanakan dan melakukan penilaian pembelajaran

$\begin{array}{ll}\text { How to cite: } & \text { Suhairi dan Jumara Santi (2021) Model Pembelajaran Blended Learning Pada Masa Pandemi Covid- } \\ & \text { 19, Syntax Literate: Jurnal Ilmiah Indonesia. 6(4). http://dx.doi.org/10.36418/syntax- } \\ & \text { literate.v6i4.2472 } \\ & 2548-1398 \\ \text { E-ISSN: } & \text { Ridwan Institute }\end{array}$


berbasis blanded learning, kekuatan blended learning terletak pada lebih efisien nya pembelajaran karena guru dan murid dapat melakukan komunikasi baik melalui luring maupun daring, kelemahanya adalah peserta didik kurang aktif dalam menyampaian tanggapan di grup whatsapp dan juga praktek copy paste tugas daring antara peserta didik semakin marak. Model pembelajaran blended learning yang ideal adalah dengan mengkombinasikan pembelajaran sinkron dan asinkron.

Kata Kunci: pembelajaran; blended learning; fungsi manajemen

\section{Pendahuluan}

Pelaksanaan kegiatan pembelajaran pada masa Covid-19, setidaknya ratusan ribu sekolah ditutup dan sekitar 68 juta siswa melakukan kegiatan belajar dari rumah, serta sekitar 4 juta guru melakukan kegiatan belajar mengajar di luar sekolah dengan tujuan untuk mencegah penyebaran virus ("Kurikulum," 2020). Surat Edaran Mendikbud Nomor 4 Tahun 2020 Tentang Pelaksanaan Kebijakan Pendidikan Dalam Masa Darurat Penyebaran Corona Virus Disease (Covid-19) memfokuskan belajar dari rumah pada pendidikan kecakapan hidup antara lain mengenai pandemi Covid-19 tanpa terbebani harus menyelesaikan seluruh capaian kurikulum untuk kenaikan kelas maupun kelulusan (Mendikbud, 2020).

Wujud salah satu inovasi revolusi industri 4.0 menurut Koko Adya Winata yang harus direspon oleh dunia pendidikan yaitu mengimplementasikan model pembelajaran yang dapat menjawab tantangan revolusi 4.0 yaitu adanya Internet of Things (Winata, 2020). Oleh karena itu lembaga pendidikan harus dapat mendidik dan mengembangkan model pembelajaran yang bisa membuat peserta didik memiliki kecakapan berfikir kritis, model pembelajaran yang diterapkan dalam proses pembelajaran harus mengarahkan peserta didik mempunyai kemampuan problem solving yang baik agar dapat mengahadapi tuntutan era revolusi industri di masa pandemi covid 19 seperti saat ini (Purnama 2020, 108).

Kebijakan pemerintah yang memfokuskan untuk melaksanakan pembelajaran dari rumah dan tuntutan revolusi 4.0 tersebut membuat lembaga-lembaga pendidikan melaksanakan berbagai inovasi dalam melaksanakan proses belajar mengajar, termasuk melaksanakan pembelajaran dengan model Blended Learning.

John Merrow (2012) mengatakan pembelajaran campuran atau blended learning adalah perpaduan pembelajaran kelas tradisional dengan pembelajaran berbasis teknologi (modern) (I Ketut Widiara 2018, 51). Model Blended Learning merupakan salah satu wujud komunikasi dalam pendidikan yang memakai sumber media alternatif seperti media cetak, multimedia, video, audio, online dan offline serta interaksi tatap muka konvensional berdasarkan skenario pembelajaran yang dibuat (Rachmah 2019, 673).

Blended Learning tidak secara utuh menggantikan pembelajaran tatap muka dengan menerapkan pembelajaran sepenuhnya secara daring. Blended Learning hanya 
mendukung dan melengkapi materi yang belum tersampaikan pada saat pembelajaran di kelas (Diana, Wirawati, and Rosalia 2020, 17).

Di sisi lain, selain metode tatap muka, banyak juga metode yang cocok untuk pembelajaran online. Pembelajaran online memiliki keunggulan dalam sumber daya belajar yang disediakan, di mana guru dan siswa dapat memperoleh berbagai sumber belajar. Pembelajaran seperti ini juga memiliki kelemahan yaitu kurangnya interaksi langsung antara guru dan siswa. Hal ini mengarah pada elemen non verbal dalam interaksi yang tidak dapat dikomunikasikan dengan sempurna (Graham, Allen, \& Ure dalam Istiningsih and Hasbullah 2015, 50).

Pembelajaran yang dicampurkan dalam Blended Learning adalah dua unsur utama, yaitu pembelajaran di kelas (classrom lesson) dengan online learning. Meskipun tidak ada konsensus tentang penggunaan istilah, "Blended Learning" secara umum didefinisikan sebagai integrasi tradisional tatap muka belajar dengan pembelajaran online, sehingga memungkinkan untuk mendapatkan keuntungan dari keunggulan dari kedua metode pengajaran (Saifuddin 2017, 72).

Dalam "blended learning", siswa tidak hanya dapat mengandalkan materi yang diberikan siswa di dalam kelas, tetapi juga dapat mencari materi dengan berbagai cara, antara lain mencari perpustakaan, bertanya kepada teman sekelas atau teman secara online, membuka website, dan mencari materi pembelajaran melalui mesin pencari, Portal atau blog, atau perangkat lunak pembelajaran dan media tutorial pembelajaran lainnya (Saifuddin 2017, 72).

Tidak dapat dipungkiri bahwa multimedia sebagai produk teknologi telah memberikan kontribusi yang besar terhadap inovasi pembelajaran BL. Banados (2006) mengembangkan model pembelajaran bahasa Inggris menggunakan $\mathrm{BL}$ dan menerapkan model tersebut melalui berbagai jenis kegiatan, yaitu (1) pembelajaran otonom, (2) tatap muka, (3) online, dan (4) mingguan dengan penutur asli Tukarkan sekali. Hasil penelitian menunjukkan bahwa peserta didik dapat mencapai tujuan belajarnya melalui pengalaman belajar yang fleksibel (Ivone, Mukminatien, and Tresnadewi 2020, 20).

Selain berbagai manfaat dan keunggulan blended learning yang dijelaskan di atas, pengemasan pembelajaran dalam blended learning masih diposisikan sebagai kebutuhan sekunder. Pada jenjang pendidikan dasar (SD dan SMP), jenjang sekolah menengah bahkan jenjang pendidikan tinggi, setiap guru masih memiliki ciri-ciri pembelajaran tatap muka. Di sisi lain, media digital seperti telepon seluler telah menjadi kebutuhan para siswa dari sekolah dasar hingga perguruan tinggi. Baik guru dan dosen pendidik harus mengatasi fenomena ini dan membuatnya menjadi pembelajaran yang menarik, bermakna, interaktif dan berkembang; sikap belajar kolaboratif, berpikir kritis, kreativitas dan keterampilan komunikasi (Masitoh 2018, 19).

Selain itu, Hasil penelitian yang disampaikan oleh Muhdi dan Nurkolis menunjukkan bahwa beberapa masalah yang muncul dalam pembelajaran selama pandemi terbagi dalam tiga kategori yaitu pedagogi, teknologi dan ekonomi (Nurkolis \& Muhdi 2020, 222). Masalah terkait pedagogi antara lain: kurangnya pelatihan, 
kurangnya pengalaman, penguasaan TIK yang rendah, waktu yang terbatas dan kurangnya pengasuhan orang tua dalam mendampingi anak dalam belajar; dan masalah terkait teknologi antara lain: kurangnya infrastruktur berupa Internet/WiFi, Sinyal lemah dan tidak ada smartphone Android. Selain itu, masalah terkait ekonomi antara lain: pengangguran, pendapatan berkurang, kemiskinan meningkat, harga kuota tinggi atau paket data.(Susanti and Prameswari 2020, 51-52).

Di Provinsi Sumatera Selatan, salah satu kabupaten yang dikategorikan zona hijau adalah Kabupaten Ogan Komering Ulu Selatan. Maka, berdasarkan aturan Gubernur Sumateran Selatan, sejak awal Juli tahun 2020 lembaga pendidikan di Kabupaten Ogan Komering Ulu Selatan diperbolehkan untuk melaksanakan pembelajaran tatap muka (luring) dengan tetap memperhatikan protokol kesehatan dan ketentuan maksimal jumlah siswa perkelas yakni 18 orang.

SMP Negeri 01 Kisam Ilir adalah salah satu sekolah menengah pertama negeri di kabupaten Ogan Komering Ulu Selatan provinsi Sumatera Selatan yang dikarenakan kapasitas ruang kelas tidak mampu menampung jumlah semua murid jika perkelas dibatasi maksimal 18 orang menjadikan Model pembelajaran Blended Learning ini menjadi pilihan model pembelajaran alternatif yang dapat dilakukan pada masa pandemi Covid-19. Namun SMP Negeri 01 Kisam Ilir menemui kendala pelaksanaan pembelajaran Blended Learning dilapangan dari sisi teknologis. Sinyal yang tidak merata kualitasnya ditambah masih terdapat murid yang tidak mempunyai gawai menjadi permasalahan tersendiri dalam pelaksanaan pembelajaran Blended Learning yang diterapkan.

Masalah ini penting untuk diteliti, karena penelitian mengenai model pembelajaran blended learning yang di terapkan di sekolah khususnya pada masa pandemi Covid-19 masih terbatas jumlahnya. Sehingga peneliti memfokuskan penelitian ini pada Model manajemen pembelajaran Blended Learning pada masa Pandemi Covid-19. Adapun tujuan dari penelitian ini adalah untuk mengetahui tentang kebijakan Pembelajaran pada masa pandemi Covid-19 di Provinsi Sumatera Selatan, untuk mengetahui model manajemen pembelajaran berbasis Blended Learning yang diterapkan di SMP Negeri 01 Kisam Ilir, untuk mengetahui Kekuatan dan kelemahan model pembelajaran Blended Learning yang diterapkan dan untuk mengetahui bagaimana model pembelajaran Blended learning yang ideal yang dapat diterapkan di SMP Negeri 01 Kisam Ilir. Manfaat penelitian ini berupa Manfaat Teoritis (Theoretical Significance) dan Manfaat Praktis (Practical Significance). Manfaat teoritis yakni menambah dan memperkaya hasanah keilmuan tentang model manajemen pembelajaran blended learning yang dapat diterapkan oleh sekolah pada masa krisis seperti pandemi Covid-19. Manfaat Praktis penelitian ini dapat membantu guru dalam meningkatkan kompetensi pengelolaan pembelajaran yang dilakukan dan dapat membantu sekolah dalam memetakan efektivitas pembelajaran pada masa pandemi Covid-19. 


\section{Metode Penelitian}

Penelitian ini merupakan penelitian deskriptif dan pendekatan penelitian yang digunakan adalah penelitian kualitatif. Metode penelitian menggunakan metode kasus tunggal. Sumber data dalam penelitian ini adalah data primer dan data sekunder. Data primer diperoleh langsung di lapangan dari sumber asli yaitu SMP Negeri 01 Kisam Ilir, sedangkan data sekunder ialah data-data yang didapat dari sumber bacaan seperti buku, majalah ilmiah, dokumen pribadi dan dokumen resmi. Teknik Pengumpulan data menggunakan teknik observasi partisipan, wawancara mendalam, dan dokumentasi. Analisis data diproses melalui reduksi data, penyajian data, dan kesimpulan dan verifikasi.

\section{Hasil dan Pembahasan}

\section{A. Kebijakan Penyelenggaran pembelajaran pada masa pandemi Covid-19 di Provinsi Sumatera Selatan}

Gubernur Sumatera Selatan mengeluarkan surat edaran nomor 047/DISDIK.SS/2020 tanggal 12 Agustus 2020 tentang penyelenggaraan pembelajaran di Satuan Pendidikan PAUD/RA/SD/MI/SMP/MTs/SMA/MA/SMK/S LB dan Satuan Pendidikan Lainnya pada Tahun Ajaran 2020/2021 di masa pandemi corona virus disease 2019 (Covid-19).

Didalam surat edaran terssebut dijelaskan bahwa a) Penyelenggaraan pembelajaran di satuan pendidikan Tahun ajaran 2020/2021 pada Pendidikan Anak Usia Dini, Pendidikan Dasar dan Pendidikan Menengah di mulai pada tanggal 13 Juli 2020; b) Sambil menunggu penerapan vaksin Covid-19 dan dalam upaya mencegah angka penularan covid 19 di Sumatera Selatan yang masih tinggi, maka pembelajaran secara taatap muka di satuan pendidikan PAUD/RA/SD/MI/SMP/MTs/SMA/MA/SMK/SLB dan satuan pendidikan lainnya di sumatera selatan di daerah zona oranye, dan zona merah di masa pandemic covid 19 tidak diperkenankan, kecuali zona hijau dan zona kuning harus dikaji secara mendalam dan dilaksanakan secara bertahap atas usul dari sekolah serta izin tertulis orang tua, melibatkan komite, dewan guru, pengawas pendidikan dan sebelumnya harus mendapat rekomendasi gugus tugas covid-19 di kabupaten atau kota masingmasing dengan memastikan seluruh warga sekolah mematuhi protocol kesehatan covid 19 secara tegas dan ketat; c) Pembelajaran di satuan pendidikan PAUD/RA/SD/MI/SMP/MTs/SMA/MA/SMK/SLB dan satuan pendidikan lainnya di sumatera selatan yang masih zona oranye dan zona merah, dilakukan dengan belajar dari rumah (BDR) secara daring/online/luring/modul dan atau sejenis, dengan memanfaatkan sumber daya yang dimiliki; d) Proses KBM tatap muka di sekolah pada zona hijau dilakukan secara bertahap agar jumlah siswa per kelas dibagi dua, maksimal 18 siswa per kelas dan jumlah jam mengajar dikurangi, bagi orang tua yang belum memberi izin anak ikut tatap muka disekolah, agar difasilitasi tetapo menggunakan pembelajaran jarak jauh (PJJ) / Daring sedangkan zona kuning dapat dilakukan uji coba bertahap mulai dari tingkat SMA sederajat dan tingkat 
SMP derajat tetapi tidak dilakukan secara serentakpada semua kelas di mulai pada kelas yang tertinggi dengan jumlah siswa di bagi dua;

Dari Surat Edaran diatas, diketahui untuk pembelajaran Tahun Ajaran 2020/2021 khususnya di semester gangsal pada masa pandemi Covid-19 Gubernur Sumatera Selatan memberikan ketentuan penyelenggaran pembelajaran di satuan pendidikan berdasarkan zona penyebaran Covid-19 yakni untuk zona oranye dan merah dilarang melaksanakan pembelajaran tatap muka di sekolah, namun untuk daerah zona kuning dan zona hijau diperbolehkan untuk melaksanakan pembelajaran tatap muka disekolah dengan ketentuan maksimal jumlah siswa perkelas 18 orang dan melaksanakan protocol kesehatan yang ketat.

Untuk daerah zona kuning dan zona hijau, satuan pendidikan yang tidak memiliki ruang kelas yang cukup untuk melaksanakan ketentuan pembelajaran maksimal 18 murid per kelas dalam satu waktu mengadakan pembelajaran blended learning. Yakni jumlah siswa perkelas di bagi menjadi dua dan pola nya bergantian.

\section{B. Model Manajemen Pembelajaran Blended Learning di SMPN 1 Kisam Ilir pada masa pandemi Covid-19}

Menurut Syaiful Sagala, Konsep manajemen sebagai sebuah proses dalam pembelajaran, dimaknai sebagai suatu usaha dan sikap pimpinan (kepala sekolah) sebagai orang yang memberikan instruksi di sekolah dan usaha maupun tindak tanduk guru sebagai pengelola pembelajaran di kelas dalam rangka meraih target program sekolah dan pembelajaran (Saifulloh and Darwis 2020, 291). Sedangkan fungsi manajemen menurut William A. Shcrode dan Dan Voice, Jr, meliputi: "Perencanaan, pelaksanaan, dan evaluasi"(Agustrian, M, and Izzudin 2017, 7). Oleh karena itu untuk melihat bagaimana model manajemen pembelajaran Blended Learning di SMP Negeri 01 Kisam ilir akan dilihat berdasarkan perencanaan, pelaksanaan dan evaluasi pembelajaran pada masa pandemi covid-19.

\section{Perencanaan}

Perencanaan pembelajaran meliputi penataan guru (pendidik), peserta didik dan tenaga administrasi, penggunaan metode, material, prosedur yang merupakan unsur-unsur perangkat pembelajaran yang harus terorganisasi secara sistematis dan sistemik (Maliki and Erwinsyah 2020, 24-25).

Prosedur Kebijakan Pembelajaran Jarak jauh (PJJ) baik secara luring atau pun daring atau Belajar Dari Sekolah (BDR) melalui tatap muka harus di buat pedoman seperti Kurikulum dan lain-lainnya. Kurikulum SMPN 01 Kisam Ilir disusun oleh tim yang telah dibentuk yaitu Tim Penjaminan Mutu Satuan Pendidikan (TPMSP) untuk memungkinkan penyesuaian program pendidikan dengan kebutuhan dan potensi yang ada di sekitar sekolah. Di tengah penanganan dan pencegahan Covid-19 Kurikulum SMPN 01 Kisam Ilir ini disusun untuk tetap mewujudkan visi sekolah dengan mengakomodasi potensi yang ada untuk meningkatkan kualitas sekolah, baik dalam aspek akademis maupun non akademis, (sesuai visi dan misi). 
Strategi pembelajaran yang dilakukan adalah sesuai dengan kebijakan pemerintah pada masa transisi dan kenormalan baru, yaitu melalui kegiatan pembelajaran BDR/ atau PJJ (daring dan atau luring) dengan menyederhakan rencana pembelajaran menjadi tiga aspek, yaitu tujuan pembelajaran kegiatan pembelajaran dan penilaian. Namun saat kondisi kembali normal seperti sebelum Covid-19 maka pembelajaran akan disesuaikan dengan tuntutan dan kebijakan yang baru, yaitu tatap muka dan lain-lainnya.

Saat masa transisi menuju New Normal, pengaturan beban belajar SMPN 01 Kisam Ilir diseuaikan dengan kebijakan yang ada terutama terkait pedoman belajar saat pandemi. Selain Kurikulum, perencanaan pembelajaran juga nampak dalam penyusunan silabus dan Rencana Pelaksanaan Pembelajaran (RPP). Silabus dan RPP merupakan perencanaan operasional dalam kegiatan pembelajaran yang disusun oleh setiap guru pengampu untuk digunakan sebagai landasan dalam melaksanakan kegiatan pembelajaran.

Dalam silabus dan RPP tersebut menunjukkan bahwa guru telah merencanakan pembelajaran dengan baik, hal ini berdasarkan dari isi silabus dan RPP yang sudah berisi tentang standar kompetensi, kompetensi inti, indikator, tujuan pembelajaran, materi pembelajaran, metode pembelajaran, langkahlangkah kegiatan pembelajaran, sumber belajar, hingga penilaian yang akan dilakukan pada masa pandemi.

\section{Pelaksanaan}

SMP Negeri 01 Kisam Ilir dalam kelancaran pelaksanaan pembelajaran pada masa pandemic menerapkan beberapa hal seperti strategi dan taktik dalam pembelajaran, metode dan teknik pembelajaran, serta prosedur pembelajaran.

\section{a) Strategi pembelajaran}

Strategi pembelajaran yang dilakukan adalah sesuai dengan kebijakan pemerintah pada masa transisi dan kenormalan baru, yaitu melalui kegiatan pembelajaran BDR/atau PJJ (daring dan atau luring) yakni dengan model pembelajaran Blended Learning.

Dalam proses implementasinya, Tomlinson dan Whitaker (2013) meringkas konsep taksonomi BL dari Smith dan Kurthen (2007), dan Gruba dan Hinkelman (2012) menyebutkan 4 jenis, yaitu web enhancement, hybrid, hybrid dan sepenuhnya online (Ivone, Mukminatien, and Tresnadewi 2020, 19). Tabel di bawah ini menjelaskan klasifikasi mode pembelajaran yang dikelompokkan berdasarkan rasio waktu pembelajaran online terhadap waktu pembelajaran tatap muka. 
Tabel 1

Taksonomi Blended Learning

\begin{tabular}{lll}
\hline No & Jenis & Deskripsi \\
\hline 1. & Web-enhanced & $\begin{array}{l}\text { Pembelajaran yang hanya sedikit } \\
\text { memanfaatkan teknologi online sebagai } \\
\text { penunjang tatap muka }\end{array}$ \\
\hline 2. & Blended & $\begin{array}{l}\text { Memanfaatkan teknologi dengan aktivitas } \\
\text { online yang signifikan sampai dengan 45\% }\end{array}$ \\
\hline 3. & Hybrid & $\begin{array}{l}\text { Kegiatan belajar yang menggunakan kegiatan } \\
\text { belajar online dengan porsi lebih banyak, } \\
\text { sekitar 45\%-80\% }\end{array}$ \\
\hline 4. & Fully online & $\begin{array}{l}\text { Materi dan kegiatan belajar yang dilaksanakan } \\
\text { dengan porsi online di atas 80\% }\end{array}$ \\
\hline & & (Ivone et al., 2020)
\end{tabular}

Pada tabel di atas, desain pembelajaran BL membutuhkan penggunaan teknologi dimana aktivitas online mencapai hingga 45\% dari keseluruhan proses pembelajaran. Dalam pembelajaran BL ini setidaknya terdapat dua makna yaitu integrasi tatap muka dan integrasi online. Pertama, desain pembelajaran memerlukan kurikulum/silabus yang memuat uraian rangkaian kegiatan pembelajaran, termasuk kegiatan tatap muka dan kegiatan non tatap muka yang diatur oleh prinsip dan tugas dalam lingkungan belajar yang terstruktur (Tomlinson, 2013). Kedua, guru dituntut mampu mendesain pengalaman belajar yang memanfaatkan berbagai media cetak dan elektronik untuk memberikan kesempatan kepada siswa dalam mencapai literasi multimedia (Mukminatien, 2012; Tungka \& Mukminatien, 2016). Jika desainnya masuk akal, BL akan membawa manfaat yang sangat besar untuk pembelajaran, karena platform online dapat mendukung komunikasi tatap muka, begitu pula sebaliknya (Ivone, Mukminatien, and Tresnadewi 2020, 20).

Kegiatan Pembelajaran SMPN 01 Kisam Ilir dilaksanakan dengan sebelumnya berkoordinasi dengan Dinas Pendidikan Kabupaten OKU Selatan yaitu sesuai protokol dan himbauan kesehatan dari Tim GugusBerkoodinasi dengan Tim Gugus Satuan Kecamata, Desa, Komite dan Warga Sekolah.Pelaksanakan beban Pembelajaran disederhanakan berdasarkan Permendikbud Nomor 4 Tahun 2020 dan Kepmendikbud Nomor 719/P/2020 jika kondisi normal bisa diberlakukan Permendikbud Nomor 37 Tahun 2018; Selama pandemi covid-19/new era normal, sekolah tidak menyelenggarakan kegiatan kesiswaan ekskul dan lainnya.

Pelaksanakan Kegiatan Pembelajaran dan Penilaian di SMP Negeri 01 Kisam Ilir disesuaikan dengan kondisi pandemi, sehingga belajar berdasarkan PJJ, Darling dan Luring yaitu Shift Genap Ganjil dengan jeda per-shift 1 minggu sekali, dan disesuaikan jika kondisi sudah pulih/Normal bisa diberlakukan jadwal belajar yang reguler efektif. 
Dalam Pelaksanaan belajar Luring/Tatap Muka di SMPN 01 Kisam Ilir selama pandemi covid-19, diberlakukan per-hari 2 jam Pelajaran selama 5 hari dalam 1 minggu dengan durasi permata pelajajaran 30 menit, tanpa Istirahat dan dengan protokol kesehatan; Selama BDR Beban belajar di SMPN 01 Kisam Ilir dinyatakan dalam jam pembelajaran per minggu. Beban belajar satu hari 2 Jam Pelajaran Kelas VII, VIII, dan IX adalah 10 jam pembelajaran. Durasi setiap satu jam pembelajaran adalah 30 menit.

Untuk waktu jeda pembelajaran 1 minggu, pelaksanaan Pembelajaran dilaksanakan secara daring dan digunakan untuk kegiatan terstruktur atau Kegiatan Mandiri Terstruktur (KMT) dan Kegiatan Mandiri Tidak Terstruktur (KMTT) seperti terlihat pada tabel di bawah ini:

Tabel 2

Kegiatan Pembelajaran SMPN 1 Kisam Ilir pada Masa Pandemi Covid-19

\begin{tabular}{ll}
\hline \multicolumn{1}{c}{ Kegiatan } & \multicolumn{1}{c}{ Luring/Daring } \\
\hline $\begin{array}{l}\text { Tatap Muka per } \\
\text { Mata Pelajaran }\end{array}$ & Luring \\
\hline Penugasan Terstruktur & Daring \\
\hline $\begin{array}{l}\text { Kegiatan Mandiri Tidak } \\
\text { Terstruktur }\end{array}$ & Daring \\
\hline
\end{tabular}

Dari penjelasan diatas, dapat dikatakan bahwa persentasi dalam konsep pembelajaran luring dan daring di SMP Negeri 01 Kisam Ilir adalah $50 \%$ tatap muka dan 50\% nya lagi daring, namun dalam keefektifan penerapan dilapangan pembelajaran tatap muka mengambil porsi $55 \%$ dan daring $45 \%$ dari total pelaksanaan pembelajaran. Pembelajaran melalui daring atau online Dianggap tidak mencapai 50\% karena beberapa guru menginginkan tugas yang dibuat selama pembelajaran daring tidak sepenuhnya harus dikirim secara daring pula, namun dikirim melalui pertemuan saat luring. Ini berarti SMP negeri 01 Kisam Ilir telah melaksanakan pembelajaran Blended Learning berdasarkan taksonomi BL oleh Smith dan Kurthen yang mensyaratkan Pembelajaran online mencapai $45 \%$.

Lebih lanjut, SMP Negeri 01 Kisam Ilir mengenai Beban belajar saat kondisi telah dinyatakan normal, maka beban belajar ditentukan berdasarkan penggunaan sistem pengelolaan program pendidikan yang berlaku di sekolah pada umumnya saat ini, yakni menggunakan sistem paket.

\section{b) Metode Pembelajaran}

Dalam interkasi Kegiatan belajar mengajar terdapat komunikasi antara pemberi pesan dan penerima pesan, serta materi pesan yang disampaikan. Nofrion mengungkapkan pengajar menyampaikan pesan yang berupa materi pembelajaran kepada pembelajar atau peserta didik yang menerima pesan tersebut. Komunikasi dalam pembelajaran bisa dilakukan searah, interaktif 
maupun ada transaksi yang dinamis antara pengirim dan penerima pesan (Pusvyta Sari, Luthfah Nur Aini 2021, 25).

Proses komunikasi pembelajaran harus dilanjutkan dalam pembelajaran offline, online, dan campuran (keduanya). Untuk model pembelajaran "blended learning", dipercaya bahwa siswa telah mandiri melalui pembelajaran ini dan bertanggung jawab atas pembelajarannya sendiri. Suasana belajar blended learning akan "memaksa" siswa untuk belajar secara aktif. Siswa akan secara mandiri mencari informasi dan materi pembelajaran, berinisiatif melakukan tindakan, dan belajar secara mandiri. (Damanik 2019, 806).

SMP Negeri 01 Didalam pelaksanaan pembelajaran luring, metode pembelajaran yang digunakan sama di saat seperti pembelajaran normal, seperti ceramah, diskusi, project bases learning dan lain sebagainya. Di dalam pembelajaran daring menggunakan berbagai platform media daring dalam menunjang pelaksanaanya. Didalam penggunaan model pembelajaran blended learning dalam upaya menggabungkan pembelajaran daring dan luring perlu adanya inovasi pembelajaran dalam memfasilitasi pembelajaran dengan model gabungan tersebut.

Inovasi pembelajaran merupakan suatu upaya yang bertujuan untuk mengkoordinasikan perkembangan ilmu pengetahuan dan teknologi ke dalam proses pembelajaran, sekaligus memecahkan berbagai masalah dalam proses pembelajaran. Seperti yang dikatakan oleh Nurul Zuriah dan Hari Sunaryo: "Inovasi dalam pendidikan dan pembelajaran adalah untuk menyelesaikan pendidikan dan Upaya untuk mempelajari masalah."(Halik 2013, 45) oleh karena itu teknologi utama nya internet sangat dibutuhkan dalam pembelajaran dengan model blended learning.

Padahal, Internet memang dapat digunakan dalam proses pembelajaran karena memiliki banyak karakteristik yang unik, yaitu (1) sebagai salah satu media interpersonal dan media massa yang memungkinkan terjadinya komunikasi one-to-one dan one-to-many, (2) bersifat interaktif . (3) Memungkinkan komunikasi sinkron atau asinkron, sehingga terwujud pembelajaran yang tidak pernah mengenal waktu dan tempat (Badaruddin et al. 2018, 236).

Oleh karena itu pada keadaan normal baru saat ini proses pembelajaran dapat berjalan dengan efektif, kita dapat belajar melalui media elektronik dan jaringan internet melalui kombinasi pembelajaran sinkron dan asinkron. Adapun Bagan di jelaskan sebagai berikut: 


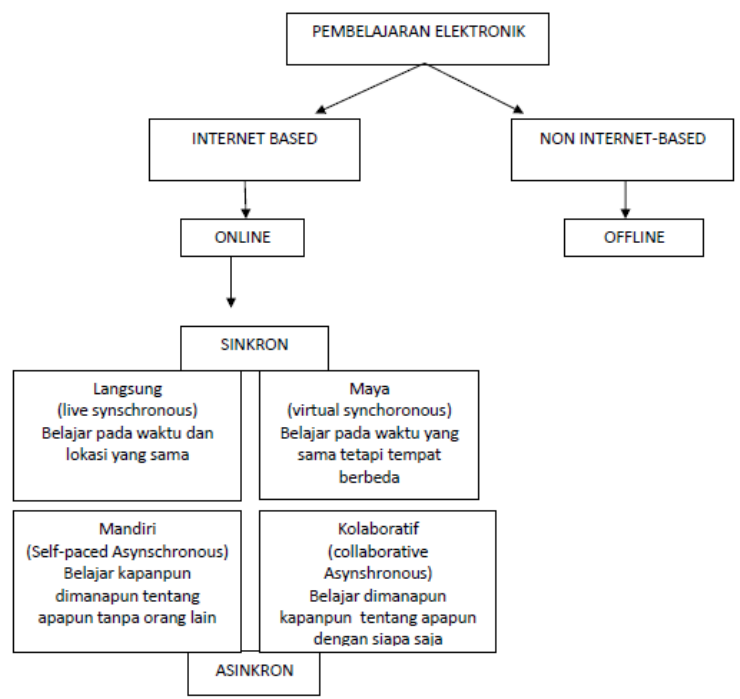

\section{Gambar 1 Pembelajaran Sinkron dan Asinkron}

Sumber: (Purnama 2020, 112)

Dari gambar di atas dapat dijelaskan bahwa:

1. Sinkronisasi langsung (SL), yaitu proses pembelajaran yang menuntut pendidik dan siswa untuk bertemu pada waktu dan tempat yang sama. Kegiatan pendidikan yang berlangsung adalah ceramah, diskusi dan praktek di lapangan, sehingga sama dengan pembelajaran tatap muka.

2. Sinkron Maya (SM), melibatkan pendidik dan peserta didik dalam proses belajar mengajar, mereka mengikuti pembelajaran yang sama, namun berbeda posisi antara satu sama lain. Kegiatan pembelajaran dalam sinkronisasi virtual dapat dilakukan dengan menggunakan teknologi sinkronisasi misalnya dalam bentuk video conference, Google Meet, Zoom, audio conference atau seminar berbasis web (web seminar)

3. Asinkron Mandiri (AM), proses kegiatan pengajaran online dilakukan secara terpisah. Siswa dapat belajar kapan saja dan dimana saja sesuai dengan kecepatan kemampuan menangkapnya sendiri. Kegiatan belajar mandiri asinkron meliputi menonton, membaca, menyimak, berlatih, dan meniru menggunakan materi digital yang sesuai dengan tema atau materi pembelajaran. Kegiatan belajar secara mandiri asynchronous terutama menggunakan pembelajaran online, meskipun ada juga pembelajaran offline.

4. Asinkron Kolaboratif (AK). Ini adalah proses pembelajaran kolaboratif (bersama) di antara anggota kelas atau nara sumber lainnya. Kegiatan pembelajaran asynchronous kolaboratif termasuk berpartisipasi dalam diskusi melalui forum diskusi online, milis online, tugas mandiri dan kelompok online, dan mempublikasikan hasil tugas independen atau kelompok ke jurnal, blog, wiki, dll. 
Kombinasi pembelajaran under the new normal saat ini merupakan metode pembelajaran yang efektif. Pada prinsipnya blended learning menggabungkan pembelajaran tatap muka dengan pembelajaran online menggunakan berbagai platform. Sebagai contoh, sistem pengelolaan pembelajaran yang umum digunakan adalah portal e-learning milik institusi atau selain menggunakan google clasroom, banyak aplikasi konferensi video digunakan, termasuk google meet dan zoom. Selain itu, watshapp group juga digunakan untuk melakukan proses pembelajaran online (Purnama 2020, 112-113).

Penggunaan grup whatsapp untuk mendukung komunikasi dalam pembelajaran meliputi penggunaan teknologi informasi dan komunikasi (TIK) untuk pendidikan. Dalam kehidupan sehari-hari penggunaan TIK sangat mudah, dalam proses pembelajaran juga memberikan kemudahan dan peluang yang baik untuk mencapai tujuan pembelajaran (Pusvyta Sari, Luthfah Nur Aini 2021, 26).

Di SMP Negeri 01 Kisam Ilir, penerapan pembelajaran Blended Learning terutama dalam pengoptimalan internet lebih kepada penerapan Asinkron, belum pernah dilakukan pola sinkron atau kombinasi keduanya. Platform utama moda daring di dalam metode Blended Learning yang digunakan SMP Negeri 01 Kisam Ilir adalah Metode Blended Learning berbasis Grup Whatsapp. Grup Whatsapp ini menjadi keharusan bagi guru dalam menerapkan model pembelajaran Blended Learning pada masa pandemi covid-19, untuk metode lain seperti messenger, google classroom dibebaskan kepada guru untuk memilih moda lain sebagai opsi tambahan metode pembelajaran selain grup whatsapp sesuai dengan kemampuan operasional masing-masing guru dan siswa yang menjadi tanggung jawabnya.

Metode Blended Learning dengan menggunakan grup whatsapp ini dilaksanakan di SMP Negeri 01 Kisam Ilir dalam beberapa tahapan. pertama, guru membuat kelas/grup mata pelajaran di whatsapp dan mengundang perwakilan dari setiap kelas dalam satu generasi siswa. Kemudian, setiap perwakilan mengundang dan menambahkan semua teman satu kelas untuk bergabung dengan grup. Oleh karena itu, semua siswa di kelas telah bergabung dengan kelas/mata pelajaran grup whatsapp. Setelah menggabungkan semua konten, guru akan menjelaskan tujuan penggunaan grup whatsapp dalam topik yang diajarkan. Memungkinkan siswa untuk memahami dan menggunakannya sesuai dengan tujuan belajarnya, serta senantiasa menjaga etika bahasa dan mengirimkan informasi. Setiap siswa yang terhubung dapat membantu dan memberi tahu teman yang belum menjalin kontak dengan grup whatsapp untuk memahami pertukaran yang terjadi di grup whatsapp, baik teman-teman yang terkendala sinyal dan tidak memiliki gawai. Selain itu, guru mengirimkan silabus atau RPP dan materi 
sebelum pertemuan tatap muka. Siswa mengakses semua materi dan informasi yang berkaitan dengan pembelajaran melalui grup whatsapp. Selain itu, siswa juga dapat mengirimkan balasan, pertanyaan, dan berdiskusi dengan teman sekelas atau kelas lain.

\section{c) Evaluasi Penilaian hasil Belajar}

Menurut Ralph Tyler, evaluasi ialah proses yang menentukan sampai sejauh mana tujuan pendidikan dapat dicapai (Junanto 2016, 180). Evaluasi hasil belajar didasarkan pada penggunaan alat evaluasi oleh seseorang atau sekelompok orang untuk mengambil keputusan tentang kriteria tertentu atas hasil suatu kegiatan atau rangkaian kegiatan (hasil belajar), menurut (Arikunto, 2014) evaluasi. Hal-hal yang mempunyai hasil baik atau buruk secara terencana, teratur dan berkelanjutan, maka akan mengambil keputusan berdasarkan kriteria tertentu dengan mempertimbangkan proses, harga, nilai, atau nilai hasil belajar siswa. Ungkapan ini bermakna, yaitu: (1) Bagi siswa perlu diketahui bahwa mereka telah berhasil mengikuti kurikulum guru; (2) Guru dapat memahami tingkat keberhasilan belajar siswa, ketepatan bahan ajar dan metode yang digunakan; (3) Bagi sekolah dimungkinkan untuk mengetahui hasil belajar siswa, yaitu melihat kondisi pembelajaran yang dibuat oleh sekolah, kesesuaian mata kuliah yang digunakan, dan apakah sekolah tersebut memenuhi standar. (Nursa'ban 2010, 255-256). Penilaian pembelajaran yang dilakukan di SMP Negeri 01 Kisam Ilir adalah:

1) Penilaian Harian (PH) dilaksanakan pada setiap akhir KD.

2) Penilaian Tengah Semester ( PTS ) dilaksanakan pada setiap tri wulan.

3) Penilaian Akhir Semester (PAS) dilaksanakan pada setiap akhir semester.

4) Penilaian Akhir Tahun (PAT) dilaksanakan pada setiap akhir tahun pelajaran.

Sedangkan Hasil Rapor Mutu Standar Penilaian Pendidikan SMP Negeri 01 Kisam Ilir Masa pandemic Covid-19 tahun 2020 dapat dilihat pada tebel berikut:

Tabel 3

Nilai SNP SMPN 01 Kisam Ilir Tahun 2020 Aspek Penilaian Rapor Mutu SMPN 01 Kisam Ilir

\begin{tabular}{llc}
\hline No & Aspek & Nilai SNP \\
\hline & Standar Penilaian & $\mathbf{5 , 8 6}$ \\
\hline $\mathbf{1}$ & 4.1. Aspek penilaian sesuai ranah kompetensi & $\mathbf{5 . 2 3}$ \\
\hline 2 & $\begin{array}{l}\text { 4.1.1. Mencakup ranah sikap, pengetahuan dan } \\
\text { keterampilan Instrumen }\end{array}$ & 4.31 \\
\hline 3 & $\begin{array}{l}\text { 4.1.2. Memiliki bentuk pelaporan sesuai dengan ranah } \\
\text { Instrumen }\end{array}$ & 6.15 \\
\hline $\mathbf{4}$ & 4.2. Teknik penilaian obyektif dan akuntabel & $\mathbf{6 . 3 8}$ \\
\hline
\end{tabular}




\begin{tabular}{llc}
\hline 5 & $\begin{array}{l}\text { 4.2.1. Menggunakan jenis teknik penilaian yang obyektif } \\
\text { dan akuntabel }\end{array}$ & 7.00 \\
\hline 6 & $\begin{array}{l}\text { 4.2.2. Memiliki perangkat teknik penilaian lengkap } \\
\text { Instrumen }\end{array}$ & 5.76 \\
\hline $\mathbf{7}$ & 4.3. Penilaian pendidikan ditindaklanjuti & $\mathbf{5 . 4 5}$ \\
\hline 8 & $\begin{array}{l}\text { 4.3.1. Menindaklanjuti hasil pelaporan penilaian } \\
\text { Instrumen }\end{array}$ & 5.57 \\
\hline 9 & $\begin{array}{l}\text { 4.3.2. Melakukan pelaporan penilaian secara periodik } \\
\text { Instrumen }\end{array}$ & 5.32 \\
\hline $\mathbf{1 0}$ & 4.4. Instrumen penilaian menyesuaikan aspek & $\mathbf{6 . 0 8}$ \\
\hline 11 & $\begin{array}{l}\text { 4.4.1. Menggunakan instrumen penilaian aspek sikap } \\
\text { Instrumen }\end{array}$ & 3.95 \\
\hline 12 & $\begin{array}{l}\text { 4.4.2. Menggunakan instrumen penilaian aspek } \\
\text { pengetahuan Instrumen }\end{array}$ & 7.00 \\
\hline 13 & $\begin{array}{l}\text { 4.4.3. Menggunakan instrumen penilaian aspek } \\
\text { keterampilan Instrumen }\end{array}$ & 7.00 \\
\hline $\mathbf{1 4}$ & 4.5. Penilaian dilakukan mengikuti prosedur \\
\hline 15 & $\begin{array}{l}\text { 4.5.1. Melakukan penilaian berdasarkan penyelenggara } \\
\text { sesuai prosedur }\end{array}$ & $\mathbf{6 . 1 8}$ \\
\hline 16 & $\begin{array}{l}\text { 4.5.2. Melakukan penilaian berdasarkan ranah sesuai } \\
\text { prosedur Instrumen }\end{array}$ & 5.37 \\
\hline 17 & $\begin{array}{l}\text { 4.5.3. Menentukan kelulusan siswa berdasarkan } \\
\text { pertimbangan yang sesuai }\end{array}$ & 6.70 \\
\hline
\end{tabular}

Pada bagian Kategori Nilai Capaian SNP akan memberikan beberapa informasi mengenai pencapaian nilai standar nasional pendidikan yang disajikan dalam bentuk kategori $1-\mathrm{V}$, I, dengan nilai rataan $0-2,04$ II: Menuju SNP 2, dengan nilai rataan 2,05 - 3,70 III: Menuju SNP 3, dengan nilai rataan 3,71 - 5,06 IV: Menuju SNP 4, dengan nilai rataan 5,07 - 6,66 V: Memenuhi SNP, dengan nilai rataan 6,67-7,0.

Dari Tabel diatas, secara keseluruhan penilaian pendidikan yang diadakan di SMP Negeri 01 Kisam Ilir pada masa pandemi Covid-19 menunjukan nilai 5,86 yang berarti menuju SNP 4 dan kurang 0,81 poin untuk masuk dalam kategori memenuhi SNP

\section{Kekuatan dan kelemahan Manajemen Pembelajaran Blended Learning di SMPN 1 Kisam Ilir pada masa pandemi Covid-19}

Menggabungkan sumber belajar tradisional dan online adalah keputusan demokratis yang bertujuan untuk menjembatani penyebaran cepat sumber daya $e$ learning dan menghilangkan kesulitan sumber belajar yang digunakan di ruang kelas tradisional. Dengan kata lain, apapun teknologi yang digunakan, e-learning tidak dapat menggantikan realisasi pembelajaran tatap muka, karena metode interaksi tatap muka tradisional masih lebih efektif daripada pembelajaran online atau e-learning. Selain itu, aksesibilitas internet, perangkat keras (hardware) dan perangkat lunak (software) serta pembatasan pembiayaan seringkali menjadi kendala dalam memaksimalkan sumber belajar online. Oleh karena itu, 
Hendrastomo meyakini bahwa penggunaan sumber daya digital dan online untuk $e$ learning masih dipandang sebagai pelengkap metode pembelajaran tradisional. Di sini, pentingnya mengembangkan model pembelajaran dan menggabungkan sumber belajar tradisional dan digital atau online (Yaumi and Damopolii 2017, 136).

Keterbatasan ruang dan waktu belajar selama pandemi dapat diatasi dengan menerapkan pembelajaran online, namun pembelajaran tatap muka tidak dapat digantikan dengan pembelajaran online. Siswa tetap membutuhkan bimbingan dan interpretasi langsung terhadap materi yang diarahkan oleh guru. Materi tertentu tidak dapat dipelajari hanya dengan mengirimkan materi secara online, seperti biologi, yang memerlukan praktik atau eksperimen untuk membuktikan teorinya. (Utari, Yaumul, and Gaffar 2020, 263).

Keunggulan blended learning dan perkembangan blended learning disebabkan oleh kelemahan dalam pembelajaran tatap muka dan pembelajaran online. Selain perkembangan kelemahan dari kedua mata kuliah tersebut, perkembangan blended learning juga dikarenakan keunggulan pembelajaran tatap muka (face-to-face) dan e-learning. Adapun kelebihan dari Blended Learning yaitu: a) Dengan menggunakan materi yang disediakan online, siswa bebas mempelajari topik secara mandiri b). Siswa dapat berkomunikasi/berdiskusi dengan guru atau siswa lain yang tidak harus tatap muka di kelas c). Guru dapat dengan tepat mengelola dan mengontrol aktivitas belajar siswa di luar waktu tatap muka d). Guru bisa menambah kekayaan materi melalui fasilitas internet e). Guru dapat meminta siswa untuk membaca materi atau mengikuti tes yang diselesaikan sebelum pembelajaran f). Guru dapat mengelola tes, memberikan umpan balik dan menggunakan hasil tes secara efektif. g). Siswa dapat berbagi file dengan siswa lain (Wardani, Toenlioe, and Wedi 2018, 14-15).

Panambaian menjelaskan bahwa dalam program "blended learning” juga penting untuk meningkatkan interaksi antara guru dan siswa. Hal ini karena faktor jarak menghalangi guru dan siswa untuk bertemu langsung di dalam kelas. Oleh karena itu ketika pembelajaran terjadi di Internet, guru hendaknya terus memberikan rangsangan untuk merangsang siswa berkomunikasi dengan guru secara teratur, sehingga membuka suasana belajar. Padahal, hal ini tidak menutup kemungkinan tugas pembahasan ditentukan oleh guru di antara siswa di kelas (Susanti and Prameswari 2020, 51).

Di SMP Negeri 01 Kisam Ilir ada beberapa permasalahan yang timbul. Antara lain, kurangnya umpan balik dari siswa siswi dan semakin minim partisipasi dalam diskusi di grup whatsapp. dan juga praktek copy paste tugas daring antara peserta didik semakin marak. Sinyal yang tidak merata di setiap desa menjadikan komunikasi di grup whatsapp menjadi tidak efektif.

Kekuatan model pembelajaran blended learning yang dilakukan di SMP Negeri 01 Kisam Ilir adalah siswa siswi mempunyai kesempatan yang lebih besar dalam mengeksloprassi pembelajaran secara mandiri, dapat bertanya hal yang tidak dimengerti kepada guru lebih sering dan intens yang tidak terbatas ruang kantor dan 
kelas dan guru dapat memantau lebih cermat keseriusan siswa siswi dalam mengikuti pembelajaran maupun penugasan yang diberikan.

\section{Model Pembelajaran Blended Learning Ideal yang dapat di terapkan di SMP Negeri 01 Kisam Ilir}

Model pembelajaran blended learning yang ideal adalah dengan mengkombinasikan pembelajaran sinkron dan asinkron. Diadaptasi dari Chaeruman (2017) ada lima langkah utama dalam mengkonstruksi pembelajaran Blended Learning, sebagai berikut. Langkah 1. Kembangkan hasil belajar. Hasil belajar merupakan hasil belajar siswa pada tingkat mata pelajaran setelah mengambil suatu mata pelajaran dalam proses pembelajaran. Langkah 2. Petakan dan atur materi pembelajaran. Pemetaan dan pengorganisasian materi pembelajaran merupakan upaya untuk menentukan materi pembelajaran sebagai topik, subtopik dan topik berdasarkan hasil belajar yang telah ditentukan. Langkah 3. Pilih dan tentukan kegiatan pembelajaran sinkron dan asinkron. Pemilihan dan penentuan kegiatan pembelajaran sinkron dan asinkron merupakan upaya untuk mengetahui apakah hasil dan topik atau subtopik tertentu dapat dicapai melalui strategi pembelajaran asinkron atau sinkron. Pada langkah ini, kriteria pemilihan dan penentuan strategi pembelajaran yang relevan akan diberikan sebagai pedoman. Langkah 4. Mendesain kegiatan belajar yang tidak sinkron. Merancang kegiatan pembelajaran asynchronous dengan mengacu pada topik yang akan ditempuh melalui strategi pembelajaran asynchronous. Tahapan ini meliputi dua langkah, yaitu: 1) menyusun desain pembelajaran asinkron sebagai gambaran umum desain; dan 2) menyusun proses pembelajaran asinkron sebagai proses pembelajaran asinkron yang lebih detail untuk setiap topik sebagai objek pembelajaran. Langkah 5. Merancang kegiatan pembelajaran yang sinkron. Perancangan kegiatan pembelajaran sinkron meliputi dua langkah, yaitu: 1) Menulis desain pembelajaran sinkron sebagai gambaran umum desain; 2) Menyusun proses pembelajaran sinkron sebagai proses pembelajaran sinkron yang lebih detail untuk setiap mata pelajaran sebagai objek pembelajaran (Darma, Karma, and Santiana 2020, 535-536).

Dengan diterapkannya pembelajaran Blended Learning dengan kombinasi pembelajaran sinkron dan asinkron, maka pembelajaran akan lebih menjadi interaktif, efektif dan menyenangkan serta dapat menghadirkan kembali suasana pertemuan tatap muka yang biasanya melalui off line menjadi tatap muka dalam bentuk online.

\section{Kesimpulan}

Pada tahun pelajaran 2020/2021 pada masa pandemi Covid-19 Gubernur Sumatera Selatan memberikan ketentuan penyelenggaran pembelajaran di satuan pendidikan berdasarkan zona penyebaran covid-19 yakni untuk zonan oranye dan merah dilarang melaksanakan pembelajaran tatap muka di sekolah, namun untuk daerah zona kuning dan zona hijau diperbolehkan untuk melaksanakan pembelajaran tatap muka disekolah 
dengan ketentuan maksimal jumlah siswa perkelas 18 orang dan melaksanakan protocol kesehatan yang ketat.

Strategi pembelajaran yang dilakukan adalah sesuai dengan kebijakan pemerintah pada masa transisi dan kenormalan baru, yaitu melalui kegiatan pembelajaran BDR/ atau PJJ (daring dan atau luring) dengan menyederhakan rencana pembelajaran menjadi tiga aspek, yaitu tujuan pembelajaran kegiatan pembelajaran dan penilaian. Di SMP Negeri 01 Kisam Ilir metode blended learning berbasis grup whatsapp menjadi keharusan bagi guru dalam menerapkan model pembelajaran blended learning pada masa pandemi Covid-19, untuk metode lain seperti messenger, google classroom dibebaskan kepada guru untuk memilih moda lain sebagai opsi tambahan metode pembelajaran selain grup whatsaap sesuai dengan kemampuan operasional masingmasing guru dan siswa yang menjadi tanggung jawabnya.

Kekuatan blended learning terletak pada lebih efisien nya pembelajaran karena guru dan murid dapat melakukan komunikasi baik melalui luring maupun daring, kelemahanya adalah peserta didik kurang aktif dalam menyampaian tanggapan di whatsapp grup dan juga praktek copy paste tugas daring antara peserta didik semakin marak. Model Pembelajaran blended learning yang ideal adalah dengan mengkombinasikan pembelajaran sinkron dan asinkron. 


\section{BIBLIOGRAFI}

Agustrian, Nyimas Lisa, M, Rizkan, \& Izzudin. (2017). Manajemen Program Life Skill Di Rumah Singgah Al-Hafidz Kota Bengkulu. Journal of Community Development, 1(1). Google Scholar

Arikunto, Suharsimi. (2014). Prosedur Penelitian: Suatu Pendekatan Praktik. Jakarta: Rineka Cipta.

Badaruddin, B., Mas'ud, Malik, Marwati Abd., Larekeng, Hajar, Siti, \& Dangnga, Muhammad Siri. (2018). Desain Pembelajaranenglish Formath Berbasis Blended Learning. Sinergitas Multidisiplin Ilmu Pengetahuan Dan Teknologi. Google Scholar

Damanik, Rizka Nurlina. (2019). Daya Tarik Pembelajaran Berbasis Blended Learning Di Era Revolusi 4.0. Prosiding Seminar Nasional Fakultas Ilmu Sosial Universitas Negeri Medan. Medan. Google Scholar

Darma, I. Ketut, Karma, I. Gede Made, \& Santiana, I. Made Anom. (2020). Blended Learning, Inovasi Strategi Pembelajaran Matematika di Era Revolusi Industri 4.0 Bagi Pendidikan Tinggi. PRISMA, Prosiding Seminar Nasional Matematika, 527539. Google Scholar

Diana, Purwati Zisca, Wirawati, Denik, \& Rosalia, Sholeha. (2020). Blended Learning dalam Pembentukan Kemandirian Belajar. Alinea: Jurnal Bahasa, Sastra, Dan Pengajaran, 9(1), 16. https://doi.org/10.35194/alinea.v9i1.763 Google Scholar

Halik, Abdul. (2013). Inovasi Teknik Pembelajaran Pendidikan Agama Islam Pada Sma Model Negeri 3 Palu. Hunafa: Jurnal Studia Islamika, 10(1), 43. https://doi.org/10.24239/jsi.v10i1.18.43-73 Google Scholar

I Ketut Widiara. (2018). Blended Learning Sebagai Alternatif Pembelajaran Di Era Digital. Purwadita, 2(2). Google Scholar

Istiningsih, Siti, \& Hasbullah, Hasbullah. (2015). Blended Learning, Trend Strategi Pembelajaran Masa Depan. Jurnal Elemen, 1(1), 49. https://doi.org/10.29408/jel.v1i1.79 Google Scholar

Ivone, Francisca Maria, Mukminatien, Nur, \& Tresnadewi, Sintha. (2020). Blended Learning Untuk Penguatan Kompetensi Guru SMA Dalam Menyongsong Abad 21. Jurnal Graha Pengabdian, 2(1). Google Scholar

Junanto, Subar. (2016). Evaluasi Pembelajaran di Madrasah Diniyah Miftachul Hikmah Denanyar Tangen Sragen. At-Tarbawi: Jurnal Kajian Kependidikan Islam, 1(2), 177. https://doi.org/10.22515/attarbawi.v1i2.176 Google Scholar

Kurikulum. (2020). 
Maliki, Putriani L., \& Erwinsyah, Alfian. (2020). Evaluasi Manajemen Pembelajaran Di Madrasah. Adaara: Jurnal Manajemen Pendidikan Islam, 10(1), 24-37. https://doi.org/10.35673/ajmpi.v10i1.854 Google Scholar

Masitoh, Siti. (2018). Blended Learning Berwawasan Literasi Digital Suatu Upaya Meningkatkan Kualitas Pembelajaran dan Membangun Generasi Emas 2045. Proceedings of the ICECRS, 1(3). https://doi.org/10.21070/picecrs.v1i3.1377 Google Scholar

Mendikbud. Edaran Mendikbud Nomor 4 Tahun 2020 Tentang Pelaksanaan Kebijakan Pendidikan Dalam Masa Darurat Penyebaran Corona Virus Disease (Covid-19). , (2020).

Nurkolis, Nurkolis, \& Muhdi, Muhdi. (2020). Keefektivan Kebijakan E-Learning berbasis Sosial Media pada PAUD di Masa Pandemi Covid-19. Jurnal Obsesi: $\begin{array}{lllll}\text { Jurnal Pendidikan Anak Usia } 212 . & .1 \text { Dini, }\end{array}$ https://doi.org/10.31004/obsesi.v5i1.535 Google Scholar

Nursa'ban, Muhammad. (2010). Evaluasi Pelaksanaan Penilaian Pembelajaran Geografi Sma Di Kabupaten Bantul. Jurnal Cakrawala Pendidikan, 2(2). https://doi.org/10.21831/cp.v2i2.344 Google Scholar

Purnama, Medina Nur Asyifah. (2020). Blended Learning Sebagai Sarana Optimalisasi Pembelajaran Daring Di Era New Normal. Scaffolding: Jurnal Pendidikan Islam Dan Multikulturalisme, 2(02), 106-121. https://doi.org/10.37680/scaffolding.v2i02.535 Google Scholar

Pusvyta Sari, Luthfah Nur Aini, Ahsanti Fiqhiyati Putri Rida Anastashfiya Ghozali. (2021). Persepsi Mahasiswa Terhadap Metode Pembelajaran Blended Learning Dengan Aplikasi Whatsapp Group Pada Mahasiswa Insud Lamongan. Mudir (Jurnal Manajemen Pendidikan), 2(1). Google Scholar

Rachmah, Huriah. (2019). Blended Learning: Memudahkan Atau Menyulitkan? Prosiding Seminar Nasional Fakultas Ilmu Sosial Universitas Negeri Medan. Medan. Google Scholar

Saifuddin. (2017). Blended Learning Sebagai Upaya Revitalisasi Pendidikan Agama Islam Pada Perguruan Tinggi Umum. Vicratina, 1(2). Google Scholar

Saifulloh, Ahmad Munir, \& Darwis, Mohammad. (2020). Manajemen Pembelajaran dalam Meningkatkan Efektivitas Proses Belajar Mengajar di Masa Pandemi Covid19. Bidayatuna: Jurnal Pendidikan Guru Mandrasah Ibtidaiyah, 3(2), 285. https://doi.org/10.36835/bidayatuna.v3i2.638 Google Scholar

Susanti, Dewi Indah, \& Prameswari, Jatut Yoga. (2020). Adaptasi Blended Learning di Masa Pandemi COVID-19 untuk Pembelajaran Bahasa Inggris di Sekolah Dasar. Jurnal Lingua Susastra, 1(2). Google Scholar 
Utari, Widi, Yaumul, Hikmawati Vitta, \& Gaffar, Aden Arif. (2020). Blended Learning: Strategi Pembelajaran Alternatif Di Era New Normal. Transformasi Pendidikan Sebagai Upaya Mewujudkan Sustainable Development Goals (SDCs) Di Era Society 5.0. Google Scholar

Wardani, Deklara Nanindya, Toenlioe, Anselmus J. E., \& Wedi, Agus. (2018). Daya Tarik Pembelajaran Di Era 21 Dengan Blended Learning. JKTP, 1(1). Google Scholar

Winata, Koko Adya. (2020). Model Pembelajaran Kolaboratif Dan Kreatif Untuk Menghadapi Tuntutan Era Revolusi Industri 4.0. Scaffolding: Jurnal Pendidikan Islam Dan Multikulturalisme, 2(1). Google Scholar

Yaumi, Muhammad, \& Damopolii, Muljono. (2017). Desain Blended Learning: Model Pemaduan Sumber Belajar Online Dan Tradisional. Prosiding Konferensi Nasional $\mathrm{Ke}$ - 6. PPS UMY. Google Scholar

\section{Copyright holder:}

Suhairi dan Jumara Santi (2021)

First publication right:

Journal Syntax Literate

This article is licensed under:

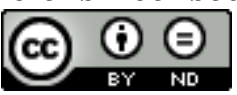

